\title{
45,X Turner's syndrome in monozygotic twin sisters
}

\author{
G. PESCIA,* P. E. FERRIER, D. WYSS-HUTIN, and D. KLEIN \\ Department of Pediatrics and Genetics, University of Geneva, Switzerland
}

\begin{abstract}
Summary. A 7-year-old girl was admitted to the hospital for anaemia, secondary to intestinal blood loss (melaena). She was found to have 45,X Turner's syndrome. Her identical twin sister also had Turner's syndrome with a 45,X chromosome complement. According to various criteria the probability of monozygosity was 0.9905 . Although the incidence of twinning is greater than usual in families of patients with Turner's syndrome, affected cases have only been observed in twin sisters on six occasions. It seems therefore that the $45, \mathrm{X}$ chromosome complement itself is not a factor predisposing to twinning, but that in some families, a factor is at play, which causes either twinning or the $45, \mathrm{X}$ aneuploidy, or both.
\end{abstract}

Turner (1938) in his original publication reported that one of his patients with the triad 'infantilism, pterygium colli and cubitus valgus' had a normal twin sister. Since Turner's original paper, the association of Turner's syndrome and twinning in the same family has been recorded on 28 occasions. The purpose of the present paper is to report the case of two monozygotic sisters with non-mosaic 45,X Turner's syndrome.

\section{Case reports}

The proposita, the second born twin, a 7-year-oldgirl, was admitted to our paediatric service for investigation of hypochromic anaemia due to recurrent melaena. Family history was negative for consanguinity, small stature, sterility, or anaemia. Twinning has occurred on two occasions on the maternal side (see pedigree, Fig. 1).

Pregnancy was complicated by protracted vomiting during the first 4 months, and by a threatened abortion at 3 months. Delivery occurred on 15 June 1966, in the estimated 30th week of gestation. V.1 weighed $1950 \mathrm{~g}$ at birth, and V.2 (propositus) $1720 \mathrm{~g}$. Placenta was unique. The mother was 22 years old and the father 23 .

The neonatal period was uneventful. Psychomotor development of both twins was slow, they walked at 18 months, and began to speak only at 4 years. Longitudinal growth was regular but slower than that of other children.

Received 4 November 1974.

* Present address: Clinique Universitaire de Pédiatrie, 30 bd. de la Cluse, 1211-Geneva 4, Switzerland.
V.2 experienced her first episode of melaena, followed by palor and fatigue, at the age of 4 years. A second episode occurred at the age of 6 years, and a third, at the age of 7 years, prompted the hospital admission. V.1 never experienced any gastrointestinal bleeding.

On physical examination (Fig. 2), the proposita (V.2) was a shy, slightly retarded (2 years retardation) 7 yearold girl. Height was $117 \mathrm{~cm}$ (10th to 25th centile) ando weight $2400 \mathrm{~g}$ (50th centile). Skin was pale, with several? pigmented naevi on the trunk and a few areas of hyperpigmentation on the extremities. Palpebral fissures were slanted downwards, and a divergent squint was

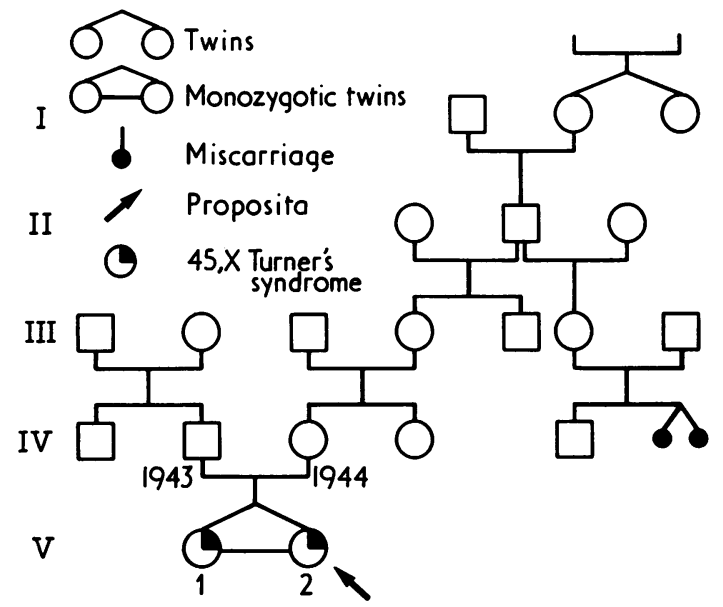

FIG. 1. Family pedigree. 


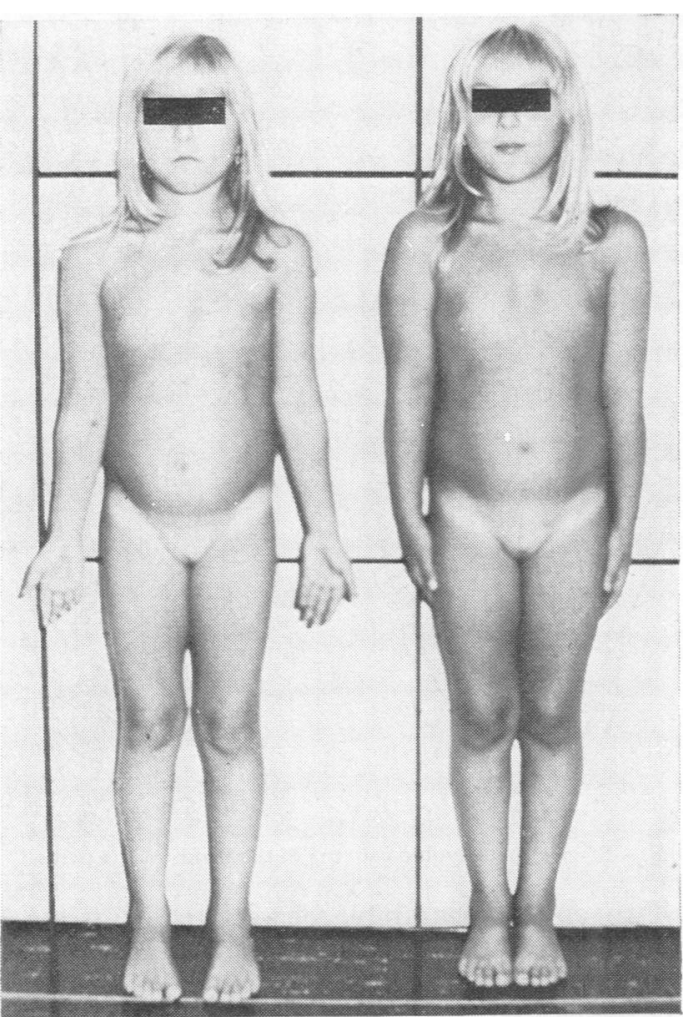

FIG. 2. The twins, aged 7. noted. The mouth was small, with an inverted $\mathrm{V}$ shape and an open bite, a narrow arched palate (Fig. 3), and irregular teeth implantation. The neck was short, without pterygium. The thyroid gland was not enlarged. On the neck, the hair was not low but it grew upwards, particularly at the sides. A discrete cubitus valgus was present on both sides and a mild hyperlaxity was noted. There was no lymphoedema. The thorax was shieldlike with widely spaced nipples. Heart and lung examination were within normal limits. There was no abdominal mass. External genitalia were those of a normal prepubertal female.

Laboratory tests confirmed the diagnosis of hypochromic anaemia secondary to intestinal blood loss. Radiology of the gastrointestinal tract failed to reveal the origin of the blood. The origin of the melaena remained therefore obscure. An intravenous pyelogram showed normal kidneys and excretory pathways.

The association of the minor physical abnormalities mentioned above with digestive bleeding (telangiectases ?) suggested the possibility of Turner's syndrome. Cytogenetic determinations were therefore undertaken in the patient and in her twin sister.

Physical examination of V.1 was similar to that of V.2 (see Fig. 2 and Table III).

\section{Cytogenetics}

Methods. Sex chromatin was examined according to the method of Moore and Barr (1955) in buccal mucosa smears, and according to that of Davidson and Robertson-Smith (1954) in peripheral leucocytes.

The chromosome complement was determined from peripheral blood lymphocyte cultures. Seabright's technique (1971) was used for examining the G-banding of chromosomes.

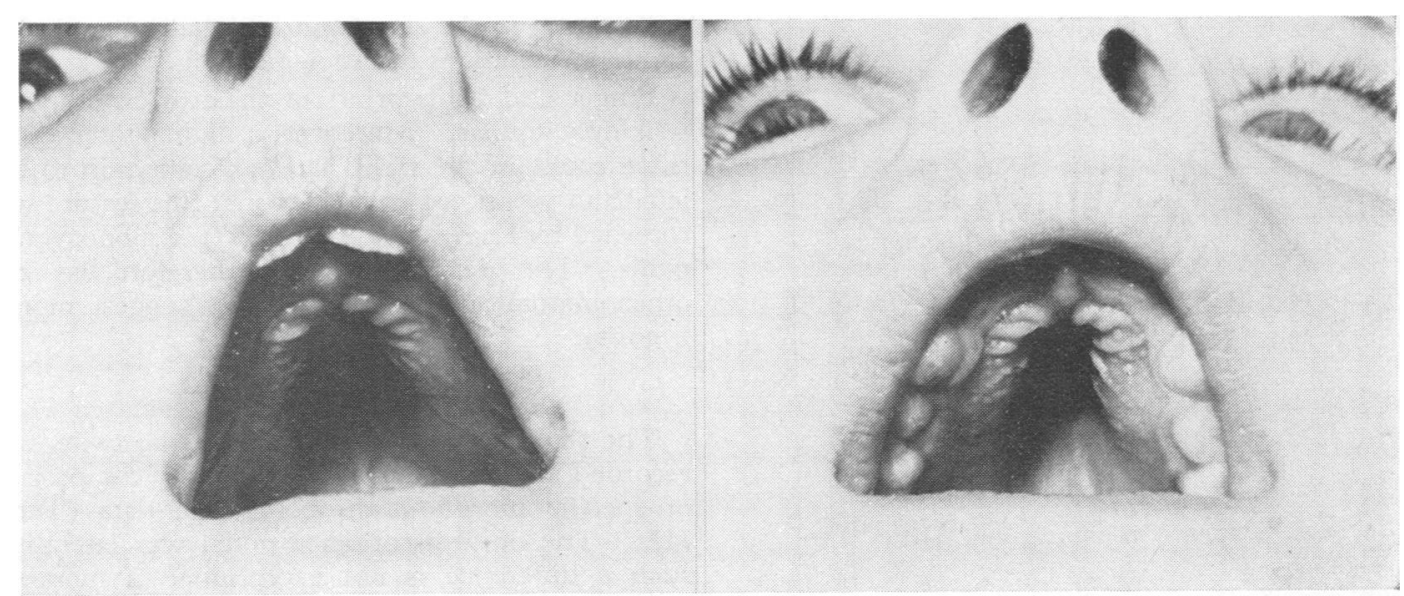

FIG. 3. The strikingly similar appearance of the mouth and palate of the twin sisters. 


\section{Results}

Sex chromatin was negative in both sisters. In both of them the chromosome complement was 45,X (Table I). The unpaired chromosome belonged to group $\mathrm{C}$, by size and morphological appearance. In this chromosome, G-bands corresponded to those of an $\mathrm{X}$ chromosome (Fig. 4). No evidence of mosaicism was found.

\section{Dermatoglyphics}

The data from the study of dermatoglyphics are summarized in Table II and Figure 5.

TABLE I

SUMMARY OF THE CYTOGENETIC DATA

\begin{tabular}{c|c|c|c}
\hline \multirow{2}{*}{ Case } & \multicolumn{2}{|c|}{ Sex Chromatin } & Chromosome \\
\cline { 2 - 3 } & Barr Bodies & Drumsticks & \\
\hline Complement \\
V.1 & $0 / 200$ & $0 / 500$ & $45, \mathrm{X}$ \\
V.2 & $0 / 200$ & $0 / 500$ & $45, \mathrm{X}$ \\
\hline
\end{tabular}

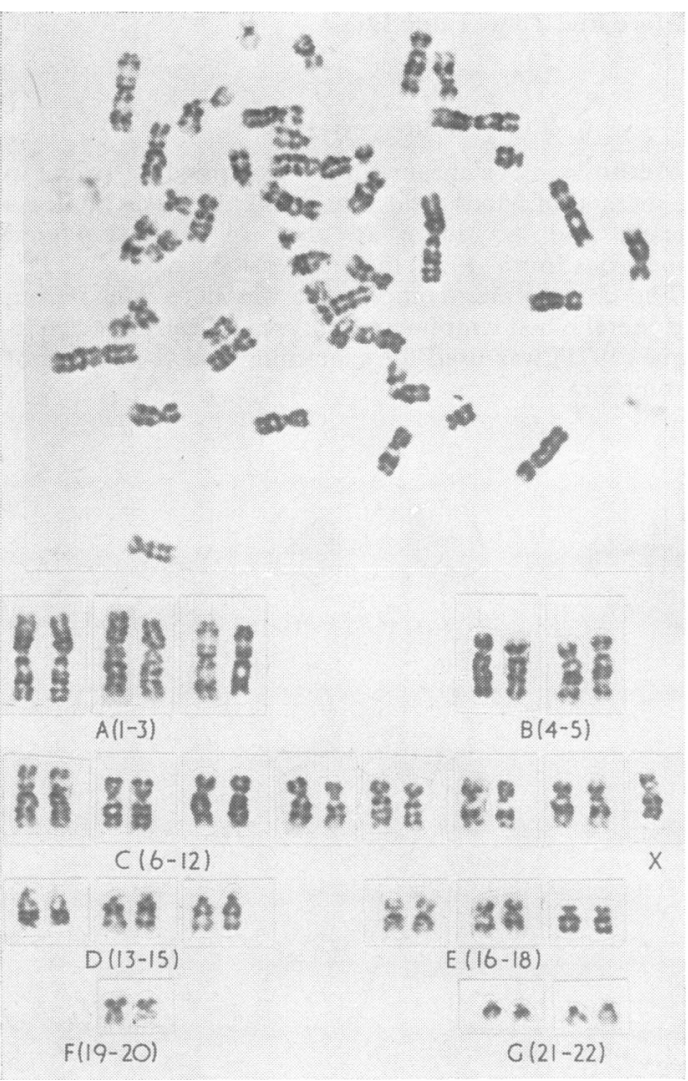

FIG. 4. 45,X karyotype of one of the twins showing G-banding.
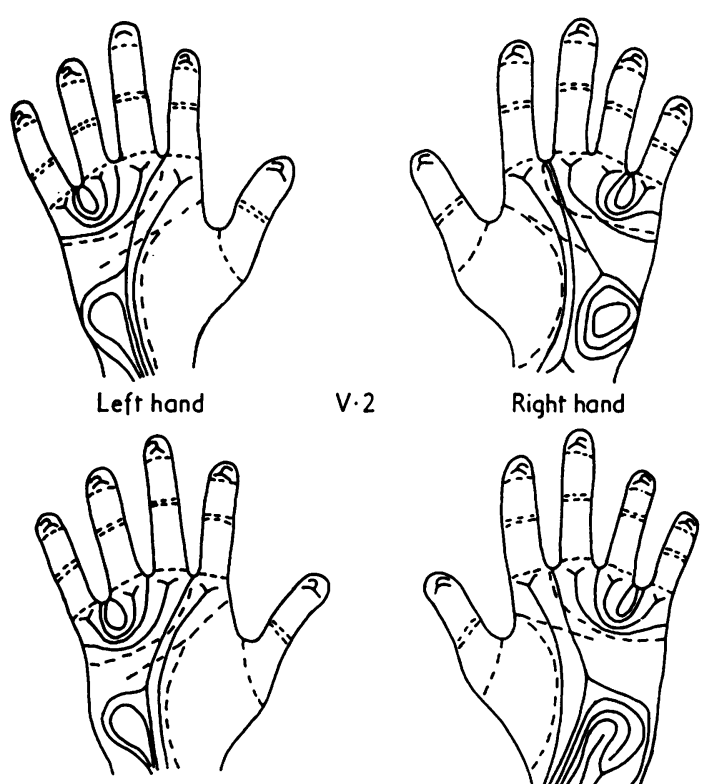

Left hand

V.1

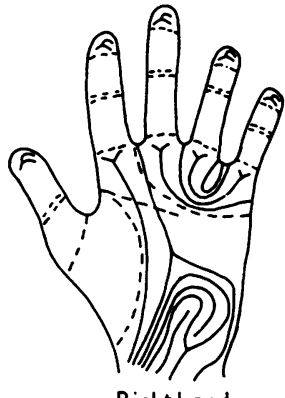

Right hand

Fig. 5. Dermatoglyphic patterns of the hands of the twins.

Two of the measurable characteristics, the $a-b$ ridge count and the maximal atd triradius angle corresponded to the values recorded in Turner's 8 syndrome (Holt and Lindsten, 1964/65). The total ridge count (TRC), by contrast, was particularly low in both sisters.

Other dermatoglyphic characteristics usually associated with Turner's syndrome were observed in the two patients: loops in both fourth interdigital areas, well developed hypothenar patterns, $T$-lines terminating in the second interdigital interval, and similar orientations of the A-line (Fig. 5).

Finger and palm prints of the two sisters were strikingly similar. Moreover, a higher total finger ridge count in the right hand as compared to the left hand was noted in both twins; this feature was recorded by Lamy et al (1956/1957) in monozygotic twins. The dermatoglyphics, therefore, as the other anatomical features, strongly suggest monozygosity.

\section{Morpho-anthropometrics}

The striking clinical similarity of the twins was recorded in a more objective fashion by comparison of specific morpho-anthropometrical data (Table III). The only discordance noted was laterality; such a difference is not exceptional in monozygotic twins. Annett (1964) constructed a model on the heredity of laterality and concluded that in the 
TABLE II

DERMATOGLYPHIC ANALYSIS

\begin{tabular}{|c|c|c|c|c|}
\hline \multirow{3}{*}{ Finger patterns } & \multicolumn{2}{|c|}{ V.1 } & \multicolumn{2}{|c|}{ V.2 } \\
\hline & Left Hand & Right Hand & Left Hand & Right Hand \\
\hline & UL, RL, UL, UL, UL & UL, UL, UL, UL, UL & UL, UL, A, UL, UL & UL, UL, UL, UL, UL \\
\hline $\begin{array}{l}\text { Position of axial triradius } \\
\text { Total ridge count }\end{array}$ & $\begin{array}{l}t^{\prime \prime} \\
23\end{array}$ & $\begin{array}{c}t, t^{\prime \prime} \\
39\end{array}$ & $t^{\prime \prime}$ & $t, t^{\prime \prime}$ \\
\hline$a-b$ ridge count & \multicolumn{2}{|c|}{89} & \multicolumn{2}{|c|}{88} \\
\hline Maximal atd angle & \multicolumn{2}{|c|}{$137^{\circ}$} & \multicolumn{2}{|c|}{$121.5^{\circ}$} \\
\hline
\end{tabular}

TABLE III

ANTHROPOMETRIC DATA FROM THE TWINS According to Martin and Saller (1957)

\begin{tabular}{|c|c|c|}
\hline & V.1 & V.2 \\
\hline $\begin{array}{l}\text { Weight } \\
\text { Height }\end{array}$ & $\begin{array}{c}26.0 \mathrm{~kg} \\
118.0 \mathrm{~cm}\end{array}$ & $\begin{array}{c}24.0 \mathrm{~kg} \\
117.0 \mathrm{~cm}\end{array}$ \\
\hline $\begin{array}{l}\text { Head } \\
\text { Maximal AP diameter } \\
\text { Maximal transverse diameter } \\
\text { Head circumference } \\
\text { Inner canthal distance } \\
\text { Outer canthal distance } \\
\text { Interpupillary distance } \\
\text { Zygomatic diameter } \\
\text { Nose length } \\
\text { Nose width } \\
\text { Gonion diameter (mandible) } \\
\text { Right ear width } \\
\text { Right ear height } \\
\text { Facial height }\end{array}$ & $\begin{array}{l}163 \mathrm{~mm} \\
135 \mathrm{~mm} \\
53.5 \mathrm{~cm} \\
31 \mathrm{~mm} \\
86 \mathrm{~mm} \\
54 \mathrm{~mm} \\
99 \mathrm{~mm} \\
42 \mathrm{~mm} \\
25 \mathrm{~mm} \\
79 \mathrm{~mm} \\
30 \mathrm{~mm} \\
57 \mathrm{~mm} \\
97 \mathrm{~mm}\end{array}$ & $\begin{array}{l}160 \mathrm{~mm} \\
132 \mathrm{~mm} \\
51.3 \mathrm{~cm} \\
31 \mathrm{~mm} \\
89 \mathrm{~mm} \\
51 \mathrm{~mm} \\
99 \mathrm{~mm} \\
44 \mathrm{~mm} \\
25 \mathrm{~mm} \\
86 \mathrm{~mm} \\
35 \mathrm{~mm} \\
56 \mathrm{~mm} \\
99 \mathrm{~mm}\end{array}$ \\
\hline $\begin{array}{l}\text { Hands } \\
\text { Right hand length } \\
\text { Right hand width }\end{array}$ & $\begin{array}{r}145 \mathrm{~mm} \\
58 \mathrm{~mm}\end{array}$ & $\begin{array}{r}146 \mathrm{~mm} \\
57 \mathrm{~mm}\end{array}$ \\
\hline $\begin{array}{l}\text { Other characteristics } \\
\text { Iris pigmentation } \\
\text { Hair pigmentation } \\
\text { Skin } \\
\text { Hair } \\
\text { Hair whorl } \\
\text { Occiput } \\
\text { Nose shape } \\
\text { Forehead } \\
\text { Ears } \\
\text { Lower lip } \\
\text { Palate } \\
\text { Tongue curling } \\
\text { Laterality } \\
\text { PTC tasting }\end{array}$ & $\begin{array}{l}10 \text { (blue-green) } \\
\text { N (blond) } \\
\text { Fine, white-pink } \\
\text { Not curly } \\
\text { Whorl, clockwise } \\
\text { Slightly flattened } \\
\text { Slightly concave } \\
\text { High, slightly prominent } \\
\text { Attached earlobes } \\
\text { Moderately thick } \\
\text { Highly arched } \\
\text { Absent } \\
\text { Right handed } \\
\text { Non-taster }\end{array}$ & $\begin{array}{l}10 \text { (blue-green) } \\
\text { N (blond) } \\
\text { Fine, white-pink } \\
\text { Not curly } \\
\text { Whorl, clockwise } \\
\text { Slightly flattened } \\
\text { Slightly concave } \\
\text { High, slightly prominent } \\
\text { Attached earlobes } \\
\text { Moderately thick } \\
\text { Highly arched } \\
\text { Absent } \\
\text { Left handed } \\
\text { Non-taster }\end{array}$ \\
\hline $\begin{array}{l}\text { Indices } \\
\text { Robusticity index of KAUP: } \\
\text { weight }(\mathrm{kg}) \times 1000 \\
\text { height }(\mathrm{cm})\end{array}$ & 1.84 & 1.76 \\
\hline $\begin{array}{l}\text { Cephalic index: } \\
\frac{\text { maximum transverse diameter } \times 100}{\text { Max. AP diameter }}\end{array}$ & 82.8 & 82.5 \\
\hline Type of skull & Brachycephalic & Brachycephalic \\
\hline $\begin{array}{l}\text { Facial index: } \\
\text { face length } \times 1000 \\
\text { zygomatic diameter }\end{array}$ & 104.3 & 100.0 \\
\hline
\end{tabular}


TABLE IV

CALCULATED RELATIVE CHANCE (PROBABILITY OF A DIZYGOTIC PAIR $p^{D}$ ) IN FAVOUR OF A DIZYGOTIC TWIN PAIR

\begin{tabular}{l|l}
\hline \multicolumn{1}{c|}{ Character } & Relative Chance \\
\hline Initial odds & 2.3333 \\
\hline Likeness in sex & 0.5000 \\
Likeness in ABO & 0.6891 \\
Likeness in MNS & 0.4556 \\
Likeness in Rhesus & 0.5021 \\
Likeness in $\mathbf{P}$ & 0.8489 \\
Likeness in Kell & 0.9485 \\
Likeness in Duffy & 0.8036 \\
\hline Difference of total ridge counts & 0.2300 \\
Difference of atd angles & 1.3600 \\
Difference of height & 0.4700 \\
Difference of cephalic index & 0.5500 \\
Total relative chance, $\mathrm{p}^{\mathrm{D}}$ & 0.0096217 \\
Total chance, $\mathrm{p}^{\mathrm{D}}\left(1+\mathrm{p}^{\mathrm{D}}\right)$ & 0.0095 \\
\hline
\end{tabular}

The absolute probability of monozygotism for our twin pair is: $1 /\left(1+p^{D}\right)=0.9904699$

TABLE V

BLOOD GROUPS OF THE TWINS

\begin{tabular}{l|c|c|c|c|c|c}
\hline $\mathrm{V} .1$ & $\mathrm{O}$ & $\mathrm{MNS}_{\mathrm{s}}$ & $\mathrm{CCDee}$ & $\mathrm{PP}$ & $\mathrm{kk}$ & $\mathrm{Fy}^{\mathrm{a}} \mathrm{Fy}^{\mathrm{b}}$ \\
\hline $\mathrm{V} .2$ & $\mathrm{O}$ & $\mathrm{MNS}_{\mathrm{s}}$ & $\mathrm{CCDee}$ & $\mathrm{PP}$ & $\mathrm{kk}$ & $\mathrm{Fy}^{\mathrm{a}} \mathrm{Fy}^{\mathrm{b}}$ \\
\hline
\end{tabular}

heterozygotic situation lateralization was a variable characteristic. Furthermore, Rife (1940) observed a discordant lateralization more often in twins born in families with left handed members. In the present family, two near-relatives of the parents are left handed.

The probability of monozygosity (Table IV) was established in accordance with Smith and Penrose's statistical method (1954/1955) which takes into account sex, blood groups (Table V), and some morphological and anthropological features. The probability of monozygosity, in the present case, was 0.9905 .

\section{Discussion}

The present observation raises several interesting questions. There was very strong evidence that the 45,X sisters were monozygotic twins. Twinning occurs, on the average, once in 85 pregnancies and only $25 \%$ of all twins are monozygotic. On the other hand, the incidence of 45,X Turner's syndrome in Europe and north America is estimated to be of 1/3000 female births (Mikamo and de Watteville, 1969). Therefore the occurrence of 45,X Turner's syndrome in monozygotic twins is theoretically not higher than $1 / 1000000$ pregnancies. Such an event has been recorded on six occasions. In other reported instances (Table VI) the twins

TABLE VI

TURNER'S SYNDROME AND TWINNING: LITERATURE REVIEW

\begin{tabular}{|c|c|c|c|c|}
\hline \multirow{2}{*}{ Phenotype } & \multirow{2}{*}{ Report } & \multicolumn{2}{|c|}{ Zygosity } & \multirow{2}{*}{ Chromosome Complement or Sex Chromatin } \\
\hline & & $\mathbf{M Z}$ & $\mathrm{DZ}$ & \\
\hline Female twins; both affected & $\begin{array}{l}\text { Turner and Zanartu (1962) } \\
\text { Lemli and Smith (1963) } \\
\text { Decourt et al (1964) } \\
\text { Edwards et al (1966) } \\
\text { Yarema and Borgaonkar (1970) } \\
\text { Ferrier et al (1970) } \\
\text { Riekhof et al (1972) } \\
\text { Present report }\end{array}$ & $\begin{array}{l}+ \\
+ \\
+ \\
+ \\
+ \\
+ \\
+ \\
+\end{array}$ & & $\begin{array}{l}45, \mathrm{X} \text { and } 45, \mathrm{X} \\
45, \mathrm{X} \text { and } 45, \mathrm{X} \\
45, \mathrm{X} \text { and } 45, \mathrm{X} \\
46, \mathrm{X} / 45, \mathrm{X} \text { and } 46, \mathrm{XX} / 45, \mathrm{X} \\
45, \mathrm{X} \text { and } 45, \mathrm{X} \\
46, \mathrm{X} \text {, qi } / 46, \mathrm{X} / 45, \mathrm{X} \text { and } 47, \mathrm{XXX} / 46, \mathrm{XX} / 45, \mathrm{X} \\
45, \mathrm{X} \text { and } 45, \mathrm{X} \\
45, \mathrm{X} \text { and } 45, \mathrm{X}\end{array}$ \\
\hline $\begin{array}{l}\text { Female twins; one affected, one } \\
\text { unaffected }\end{array}$ & $\begin{array}{l}\text { Turner (1938) } \\
\text { Boyer et al (1961/1962) } \\
\text { Almqvist et al }(1963) \\
\text { Lindsten et al }(1962 / 1963) \\
\text { Mikkelsen et al }(1963) \\
\text { K. Benirschke and M. M. Sullivan } \\
\text { (personal communication, 1965) } \\
\text { Shine and Corney (1966) } \\
\text { Ross et al (1969) } \\
\text { Yarema and Borgaonkar (1970) } \\
\text { Potter and Taitz (1972) }\end{array}$ & $\begin{array}{l}? \\
? \\
+ \\
+ \\
+ \\
+ \\
+\end{array}$ & + & $\begin{array}{l}\text { ? and ? } \\
\text { ? and chromatin-X negative (two sets of twins) } \\
46, \mathrm{XX} \text { and } 46, \mathrm{XX}, \mathrm{qi} \\
46, \mathrm{XX} \text { and } 46, \mathrm{XX}, \mathrm{qi} \\
46, \mathrm{XX} / 45, \mathrm{X} \text { and } 46, \mathrm{XX} / 45, \mathrm{X} \\
46, \mathrm{XX} \text { and } 45, \mathrm{X} \\
46, \mathrm{XX} \text { and chromatin-X negative } \\
47, \mathrm{XXX} / 45, \mathrm{X} \text { and } 47, \mathrm{XXX} / 45, \mathrm{X} \\
46, \mathrm{XX} \text { and } 45, \mathrm{X} \\
46, \mathrm{XX} / 45, \mathrm{X} \text { and } 46, \mathrm{XX} / 45, \mathrm{X}\end{array}$ \\
\hline $\begin{array}{l}\text { Female twin: affected, male } \\
\text { twin: unaffected }\end{array}$ & $\begin{array}{l}\text { Turpin et al (1961); Turpin (1970) } \\
\text { De la Chapelle (1962) } \\
\text { Almqvist et al (1963) } \\
\text { Dent and Edwards (1965) } \\
\text { Edwards et al (1966) }\end{array}$ & $\begin{array}{l}+ \\
? \\
+ \\
+\end{array}$ & + & $\begin{array}{l}\text { 46,XY and } 45, \mathrm{X} \\
\text { ? and } 45, \mathrm{X} \\
46, \mathrm{X} \mathrm{Y} \text { and } 45, \mathrm{X} \\
45, \mathrm{X} \text { and } 45, \mathrm{X} \\
45, \mathrm{X} \text { and } 46, \mathrm{XY} / 45, \mathrm{X}\end{array}$ \\
\hline $\begin{array}{l}\text { Females twins with no } \\
\text { characteristics of Turner's } \\
\text { syndrome }\end{array}$ & $\begin{array}{l}\text { Muller et al (1970) } \\
\text { Van der Horst et al (1971) }\end{array}$ & + & & $\begin{array}{l}47, \mathrm{XXX} / 46, \mathrm{XX} / 45, \mathrm{X} \text { and } 47, \mathrm{XXX} / 46, \mathrm{XX} / 45, \mathrm{X} \\
46, \mathrm{XX} / 45, \mathrm{X} \text { and } 46, \mathrm{XX} / 45, \mathrm{X}\end{array}$ \\
\hline
\end{tabular}


were monozygotic but heterocaryotic, or monozygotic but mosaic, or dizygotic. The total number of cases of Turner's syndrome occurring in one or two of twins is relatively high (28 pregnancies, see Table VI). Nance and Uchida (1964) suggested that monozygotic twinning (which had occurred in seven out of their 34 sibships identified by the presence of a case of Turner's syndrome) was significantly more frequent than expected by chance alone in families of patients with Turner's syndrome. The present report would be in keeping with their observation.

Monozygotic twins are thought to originate from the activity of a factor operating at an early cleavage division (causing the formation of two individuals from one fertilized egg). It seems reasonable to postulate that the $45, \mathrm{X}$ aneuploidy, when it is associated with twinning, arises from the activity of the same factor, at the same period of cleavage. The high incidence of mosaicism in these pairs of twins may be taken as evidence in favour of such a postfertilization event. One may therefore conclude that in some families, a factor is at play, which causes sometimes twinning, sometimes the 45,X aneuploidy, and sometimes both. It seems likely that this factor is not the one which causes meiotic non-disjunction in the male (most frequent cause of the 45,X aneuploidy according to colourblindness and Xga studies, Polani, 1971). Indeed in the present family twinning was observed on the maternal side only.

The proposita, V.2, came to medical attention because of melaena. Occult blood loss or melaena have been reported in patients with Turner's syndrome. This is either due to telangiectasias (Haddad and Wilkins, 1959) or to ulcerative colitis (Williams et al, 1966). In V.2 appropriate investigations failed to reveal the origin of the haemorrhage, which may be the case in some instances of small telangiectasias.

\section{REFERENCES}

Almqvist, S., Lindsten, J., and Lindvall, N. (1963). Linear growth, sulphation factor activity and chromosome constitution in 22 subjects with Turner's syndrome. Acta Endocrinologica, 42, 168-186.

Annett, M. A. (1964). A model of the inheritance of handedness and cerebral dominance. Nature, 204, 59-60.

Boyer, S. H., Ferguson-Smith, M. A., and Grumbach, M. M. (1961/ 1962). The lack of influence of parental age and birth order in the aetiology of nuclear sex chromatin-negative Turner's syndrome. Annals of Human Genetics, 25, 215-225.

Chapelle, A. de la (1962). Cytogenetical and clinical observations in female gonadal dysgenesis. Acta Endocrinologica, 25, suppl. 65.

Davidson, W. M. and Robertson-Smith, D. (1954). A morphological sex difference in the polymorphonuclear neutrophil leucocytes. British Medical fournal, 2, 6-7.

Decourt, J., Lejeune, J., Michard, J. P., and Petrover, M. (1964). Syndrome de Turner haplo-X typique chez deux jumelles monozygotes. Annales d'Endocrinologie, 25, 438-440.
Dent, T. and Edwards, J. H. (1965). Monozygotic twins of different sex. In Proceedings of the XIth International Congress of Genetics. Pergamon, The Hague.

Edwards, J. H., Dent, T., and Kahn, J. (1966). Monozygotic twins of different sex. Fournal of Medical Genetics, 3, 117-123.

Ferrier, P. E., Ferrier, S. A., and Kelley, V. C. (1970). Sex chromosome mosaicism in disorders of sexual differentiation: incidence in various tissues. Fournal of Pediatrics, 76, 739-744.

Haddad, H. M. and Wilkins, L. (1959). Congenital anomalies associated with gonadal aplasia. Pediatrics, 23, 885-902.

Holt, S. B. and Lindsten, J. (1964/1965). Dermatoglyphic anomalies in Turner's syndrome. Annals of Human Genetics, 28, 87100.

Lamy, L., Frézal, J., de Grouchy, J., and Kelley, J. (1956/1957). Le nombre de dermatoglyphes dans un échantillon de jumeaux. Annals of Human Genetics, 21, 374-396.

Lemli, L. and Smith, D. W. (1963). The XO syndrome: a study of the differentiated phenotype in 25 patients. Fournal of Pediatrics, 63, 577-588.

Lindsten, J., Fraccaro, M., Ikkos, D., Kaijser, K., Klinger, H., and Luft, R. (1962/1963). Presumptive isochromosome for the long arm of $\mathrm{X}$ in man. Analysis of five families. Annals of Human Genetics, 26, 383-405.

Martin, R. and Saller, K. (1957). Lehrbuch der Anthropologie in systematischer Darstellung, Vol. 1. Fischer, Stuttgart.

Mikamo, K. and Watteville, H. de (1969). Incidence of sex chromosomal anomalies in newborn infants. International fournal of Fertility, 14, 95-100.

Mikkelsen, M., Froland, A., and Ellebjerg, J. (1963). XO/XX mosaicism in a pair of presumably monozygotic twins with different phenotypes. Cytogenetics, 2, 86-98.

Moore, K. L. and Barr, M. L. (1955). Smears from the oral mucosa in the detection of chromosomal sex. Lancet, 2, 57-58.

Muller, P., Clavert, J., Rihm, G., and Gillet, J. Y. (1970). Mosaique $45, \mathrm{XO} / 46, \mathrm{XX} / 47, \mathrm{XXX}$ chez deux jumelles monozygotes: concordances et discordances cliniques et biologiques. Annales d'Endocrinologie, 31, 1143-1152.

Nance, W. E. and Uchida, I. (1964). Turner's syndrome, twinning and an unusual variant of glucose-6-phosphate dehydrogenase. American fournal of Human Genetics, 16, 380-392.

Polani, P. (1971). Origin of sex chromosome monosomy in man. fournal of Medical Genetics, 8, 501-503.

Potter, A. M. and Taitz, L. S. (1972). Turner's syndrome in one of monozygotic twins with mosaicism. Acta Paediatrica Scandinavica, 61, 473-476.

Riekhof, P. L., Horton, W. A., Harris, D. J., and Schimke, R. N. (1972). Monozygotic twins with the Turner's syndrome. American fournal of Obstetrics and Gynecology, 112, 59-61.

Rife, D. C. (1940). Handedness with special reference to twins. Genetics, 25, 178-186.

Ross, G. T., Tjio, J. H., and Lipsett, M. B. (1969). Cytogenetic studies of presumptively monozygotic twin girls discordant for gonadal dysgenesis. Fournal of Clinical Endocrinology, 29, 440445.

Seabright, M. (1971). Rapid banding technique for human chromosomes. Lancet, 2, 971-972.

Shine, I. B. and Corney, G. (1966). Turner's syndrome in monozygotic twins. Fournal of Medical Genetics, 3, 124-128.

Smith, S. M. and Penrose, L. S. (1954/1955). Monozygotic and dizygotic twins diagnosis. Annals of Human Genetics, 19, 273289.

Turner, H. H. (1938). A syndrome of infantilism, congenital webbed neck and cubitus valgus. Endocrinology, 23, 566-574.

Turner, H. H. and Zanartu, J. Z. (1962). Ovarian dysgenesis in identical twins: discrepancy between nuclear chromatin pattern in somatic cells and in blood cells. fournal of Clinical Endocrinology, 22, 660-665.

Turpin, R. (1970). Monozygotisme hétérocaryote. Acta Geneticae Medicae et Gemellologiae, 19, 188-198. 
Turpin, R., Lejeune, J., Lafourcade, J., Chigot, P. L., and Salmon, C. (1961). Présomption de monozygotisme en dépit d'un dimorphisme sexuel: sujet masculin XY et sujet haplo-X. Comptes Rendus Hebdomadaires des Séances de l'Académie des Sciences, 252, 2945-2946.

Van der Horst, R., Frankel, J., and Grace, J. (1971). Congenital hypertrophic pyloric stenosis in phenotypic female twins with X/XX mosaicism. Archives of Diseases of Childhood, 46, 554-556.
Williams, E. D., Engel, E., Taft, P. D., and Forbes, A. P. (1966). Gonadal dysgenesis and ulcerative colitis. A case report with clinical, cytogenetical and post-mortem studies. Fournal of Medical Genetics, 3, 51-55.

Yarema, W. A. and Borgaonkar, D. S. (1970). Chromosomal and dermatoglyphic changes in twins. Acta Geneticae Medicae et Gemellogiae, 19, 405-416. 